Review Article

\title{
Pharmacological Benefits and Risk of Using Hormones in Organ Perfusion and Preservation Solutions in the Aspect of Minimizing Hepatic Ischemia-Reperfusion Injury during Storage
}

\author{
Aneta Ostróżka-Cieślik (iD) ${ }^{1}$ and Barbara Dolińska ${ }^{1,2}$ \\ ${ }^{1}$ Department of Pharmaceutical Technology, Faculty of Pharmaceutical Sciences in Sosnowiec, \\ Medical University of Silesia in Katowice, Sosnowiec 41-200, Poland \\ "Biochefa" Pharmaceutical Research and Production Plant, Sosnowiec 41-200, Poland \\ Correspondence should be addressed to Aneta Ostróżka-Cieślik; aostrozka@sum.edu.pl
}

Received 9 July 2019; Revised 31 August 2019; Accepted 23 October 2019; Published 11 November 2019

Academic Editor: Guangcun Huang

Copyright (c) 2019 Aneta Ostróżka-Cieślik and Barbara Dolińska. This is an open access article distributed under the Creative Commons Attribution License, which permits unrestricted use, distribution, and reproduction in any medium, provided the original work is properly cited.

\begin{abstract}
For several years, research has been carried out on the effectiveness of solutions for perfusion and preservation of organs, including the liver. There is a search for an optimal pharmacological composition of these solutions, allowing to preserve or improve vital functions of the organ for as long as possible until it is transplanted into a recipient. Hormones due to their properties, often resulting from their pleiotropic effects, may be a valuable component for optimizing the composition of liver perfusion and preservation solutions. The paper presents the current state of knowledge on liver perfusion and preservation solutions modified with hormones. It also shows the characteristics of the hormones evaluated, taking into account their physiological functions in the body.
\end{abstract}

\section{Introduction}

Transplantation is currently the only method of treating patients with end-stage liver failure. However, the organ shortage and limited time of graft survival outside the donor organism are a challenge for contemporary transplantology. One of the directions of obtaining grafts is the extension of criteria to accept marginal organs, including those from older people. Effective protection of hepatocytes against ischemia-reperfusion injury is therefore a challenge in the aspect of undertaking proper vital functions by the organ. For several years, research has been carried out on the effectiveness of solutions for perfusion and preservation of organs, including the liver. There is a search for an optimal pharmacological composition of these solutions, allowing to preserve or improve vital functions of the organ for as long as possible until it is transplanted into a recipient. Hormones due to their properties, often resulting from their pleiotropic effects, may be a valuable component for optimizing the composition of liver perfusion and preservation solutions.
They can minimize the risk of graft dysfunction and influence the degree of hepatocyte damage during cold ischemia. The paper presents the current state of knowledge on liver perfusion and preservation solutions modified with hormones. It also shows the characteristics of the hormones evaluated, taking into account their physiological functions in the body.

\section{Literature Search}

A systematic review of the literature was carried out in accordance with the Preferred Reporting Items for Systematic Reviews and Meta-Analyses (PRISMA). The databases such as Medline, PubMed, Cochrane, and Embase had been searched until May 31, 2019. They were searched for articles on the effectiveness of liver perfusion and preservation solutions modified with hormones. Review papers and the reference lists of papers were also browsed to identify additional articles. The review also includes studies published between January 1, 1998, and May 31, 2019. Each 
article was evaluated by two authors using a structured assessment tool. Articles in English relating to studies using animal liver perfusion and preservation models, in which each species, age, sex, race, and sample size were taken into account, were included. There were no prospective, multicentre, or randomized studies with a control group carried out in humans. Studies in which the hormone was administered to the animal and/or directly to the graft at any stage of the experiment in the form of injection and/or infusion or in the diet were excluded. Only preservation solutions registered and commonly used in the liver transplantation were accepted. The terms "organ preservation solutions, therapeutic use, hormones, additives, pharmacological agent, trophic factors, perfusion, ischemiareperfusion, liver transplantation, steatotic liver models" from Medical Subject Headings (MeSH) and Emtree (Elsevier's Life Science Thesaurus) were applied with logical operators (AND, OR, and NOT).

Initially, the literature review included 777 articles related to the topic of the analysed studies. After applying the inclusion/exclusion criteria, 25 articles were qualified for the evaluation (Table 1).

\section{Preservation Solutions}

Ischemia-reperfusion injury (IRI) results in mitochondrial damage, disturbed energy metabolism, increased reactivity of free oxygen radicals (ROS), and the release of inflammatory cytokines in the liver [26-28]. To limit the occurrence of these processes, livers are stored in preservation solutions. UW (University of Wisconsin) is the most commonly used solution. It has been recognized as the gold standard for transplantology. It allows the liver to be stored for up to 12 hours by simple hypothermia. It is an intracellular fluid due to the high content of potassium $(125 \mathrm{mmol} / \mathrm{l})$ and the low content of sodium $(25 \mathrm{mmol} / \mathrm{l})$. Its disadvantages include high viscosity, which reduces perfusion efficiency, and high concentration of $\mathrm{K}^{+}$ions, which requires a preflush of liver grafts before reflow in the recipient [29]. The components that guarantee its effectiveness are lactobionate, raffinose, and glutathione. The other components have a marginal effect; therefore, it is assumed that they may be omitted. Insulin, whose action is controversial, was also introduced into the fluid composition [30]. IGL-1 (Institute George Lopez) solution was developed based on UW. The content of sodium and potassium ions was changed, and an extracellular fluid with a high $\mathrm{Na}^{+}(120 \mathrm{mmol} / \mathrm{l})$ and low $\mathrm{K}^{+}(25 \mathrm{mmol} / \mathrm{l})$ concentration was developed. The risk of cardiovascular complications was minimized in this way [31]. It has been found that in comparison with UW, it shows a more beneficial effect in the protection of fatty livers. It protects against oxidative stress, mitochondrial damage, and alterations in vascular resistance [32]. HTK (Bretschneider's solution, Custodiol) is an intracellular fluid, crystalloid, used to store the heart, liver, kidneys, and pancreas [33]. Its task is to counteract the retention of sodium and calcium ions in the intracellular space and buffer the extracellular space by means of the histidine/histidine $\mathrm{HCl}$ system during organ ischemia [34]. In turn, Ringer's solution (in combination with heparin) is used to remove residual blood in the collected organ. In the next stage of transplantation procedures, the graft is stored in a suitable preservation solution. Fluid compositions that were modified with hormones are shown in Table 2.

\section{Hormonal Additives}

4.1. Melatonin. Melatonin ( $\mathrm{N}$-acetyl-5-methoxytryptamine) is a hormone synthesized mainly in pinealocytes, and to a lesser extent in the retina, Harder's lacrimal glands, gastrointestinal tract, bone marrow cells, platelets, and lymphocytes. Its secretion depends on the diurnal cycle: light/darkness. The maximum concentration of melatonin in the blood (20-100 $\mathrm{pg} / \mathrm{ml}$ ) is observed during the night hours, between 2:00 and 4:00. The half-life of endogenous and exogenous melatonin in the blood is $30-60$ minutes and $12-48$ minutes, respectively [35-37]. The highest concentration of melatonin was determined in the hepatobiliary system $(2000-11000 \mathrm{pg} / \mathrm{ml})$ [38]. It probably protects intestinal epithelial cells from damage caused by bile acids [39]. This hormone is also found in the cerebellum, respiratory epithelium, kidneys, endothelial cells, thyroid, and ovaries [40]. The molecule of this hormone is characterized by lipophilic nature and low molecular mass (232 Da), owing to which it easily penetrates the cell membranes and diffuses into the physiological fluids of the body. Melatonin acts on target cells both by means of receptors and independently of them [41]. It has the ability to bind to intracellular proteins, receptors located in the cell membrane, and nuclear receptors. The melatonin MT1 (MTNR1A) and MT2 (MTNR1B) membrane receptors are conjugated to G proteins and are made up of 7 transmembrane hydrophobic regions with a helical structure. Nuclear receptors, in turn, belong to the ROR/RZR (retinoid orphan receptors/retinoid Z receptors) subfamily. RZR- $\beta$ is present in the nervous system cells and RZR- $\alpha$ in B lymphocytes, rat spleen, and thymus cells, as well as in hepatocytes, smooth muscle cells, and testicular cells of laboratory rodents [42-45]. It has been found that high-affinity melatonin binding sites are located in the hepatocyte nuclei [46]. Melatonin has antioxidant, angiogenetic, anti-inflammatory, immunostimulatory, and anticancer properties. It has the ability to neutralize free oxygen radicals and stimulate the action of antioxidant enzymes, i.e., superoxide dismutase, catalase, and glutathione peroxidase [47-50]. It inhibits lipid peroxidation in vivo more effectively than vitamin $\mathrm{C}$ and vitamin $\mathrm{E}$ [51]. It shows a synergistic effect with antioxidants, preventing the formation of free oxygen radicals [52].

Zaouali et al. conducted studies on the efficacy of melatonin in the protection of hepatocytes in an ex vivo model of isolated rat steatotic livers. Melatonin was added to the IGL-1 solution at a dose of $100 \mu \mathrm{mol} / \mathrm{L}$, and its activity was evaluated in relation to Ringer's lactate, IGL-1, and UW solutions. The livers were stored in the solutions for $24 \mathrm{~h}$ $\left(4^{\circ} \mathrm{C}\right)$ and then reperfused for $2 \mathrm{~h}\left(37^{\circ} \mathrm{C}\right)$. The extent of liver damage was assessed in each group and melatonin proved to have positive effects. The livers rinsed with IGL-1 with the addition of melatonin showed the lowest levels of released 


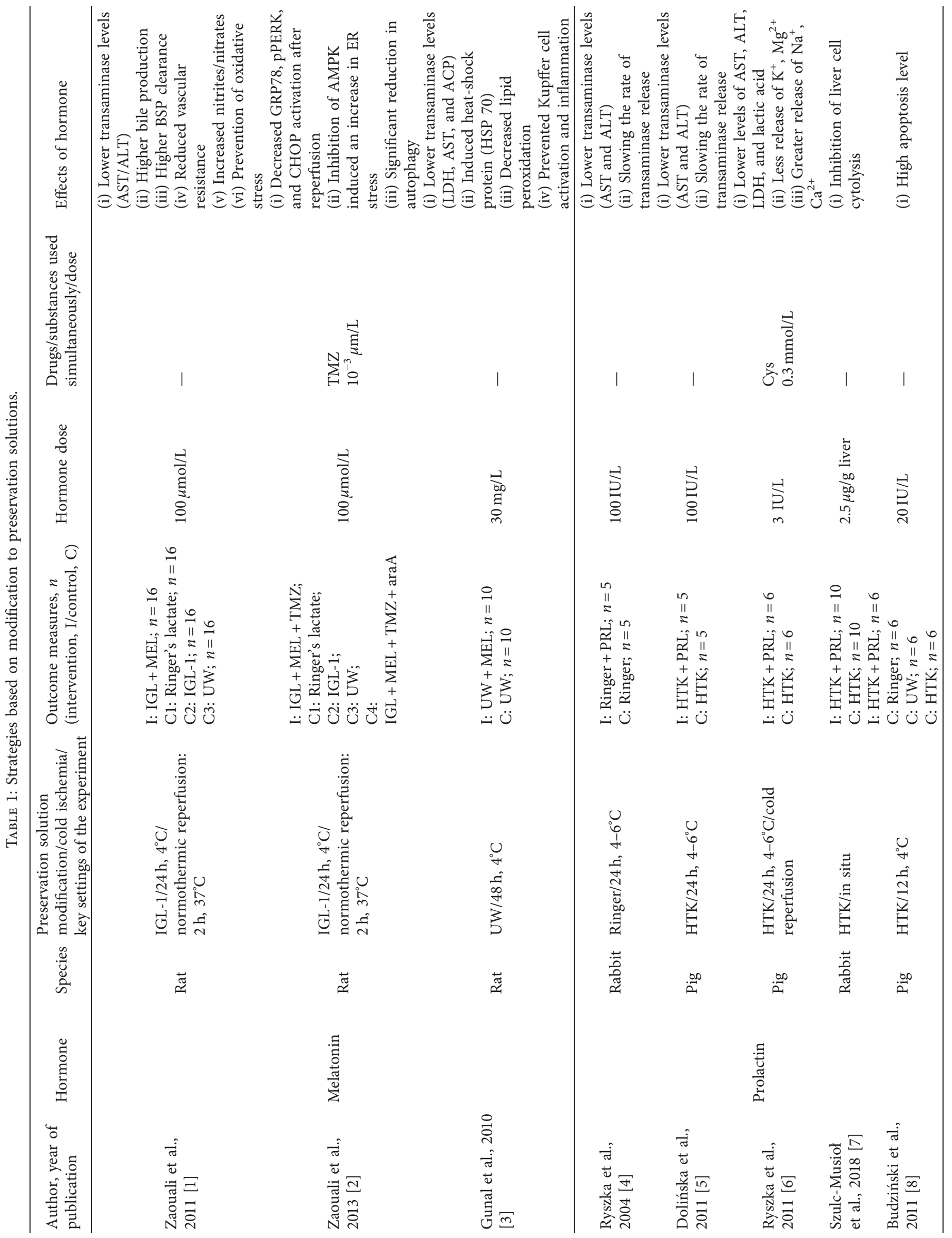




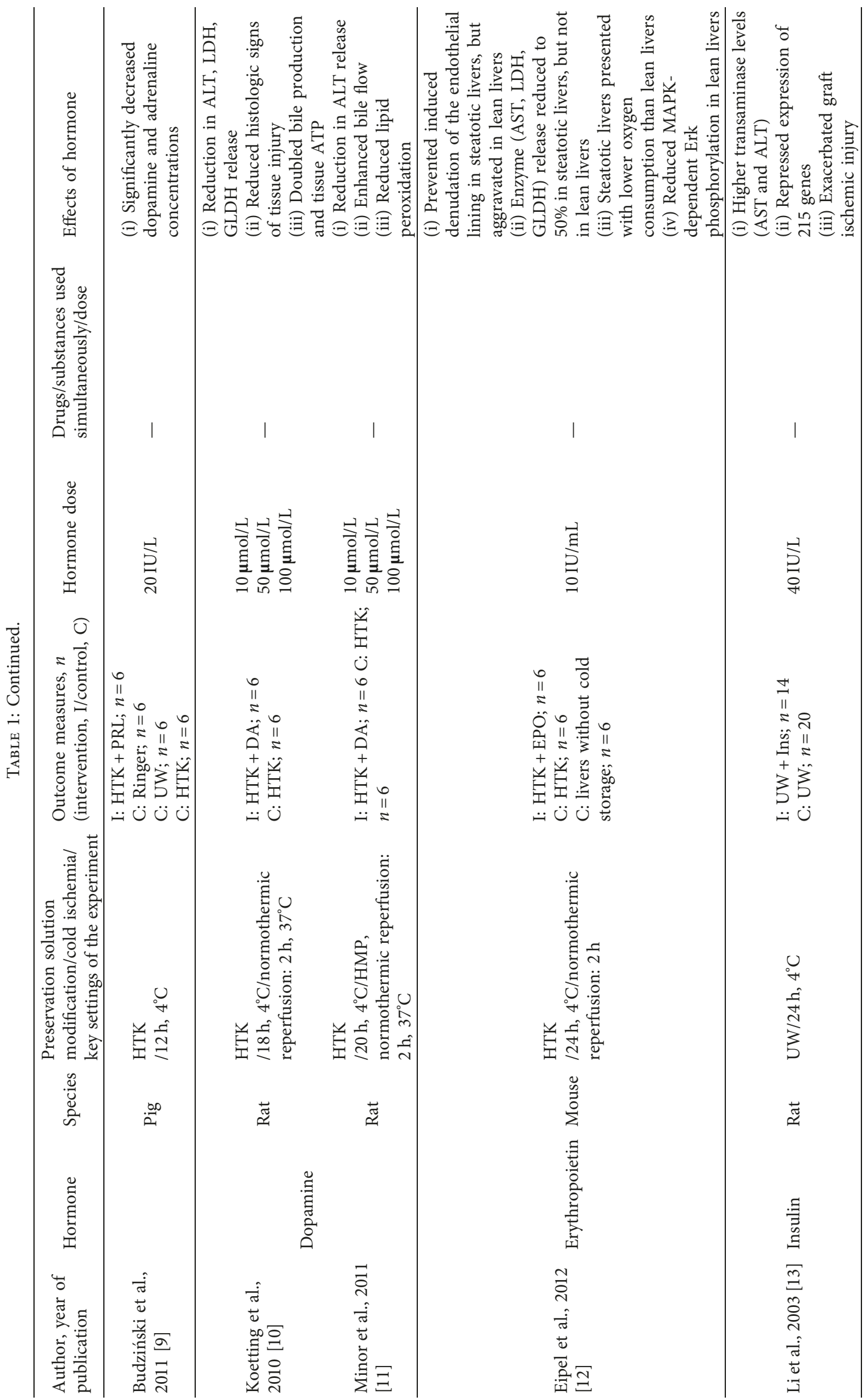




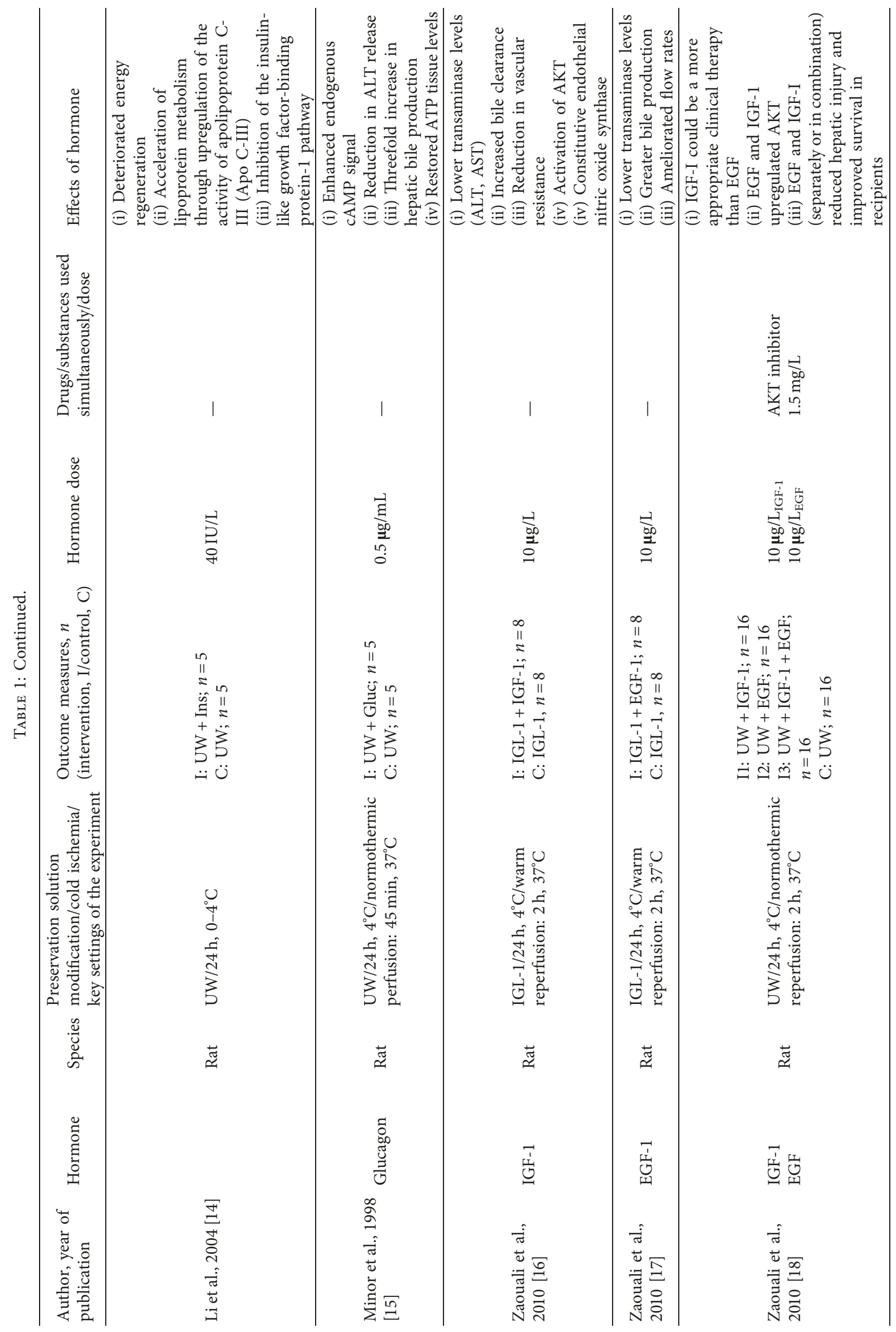




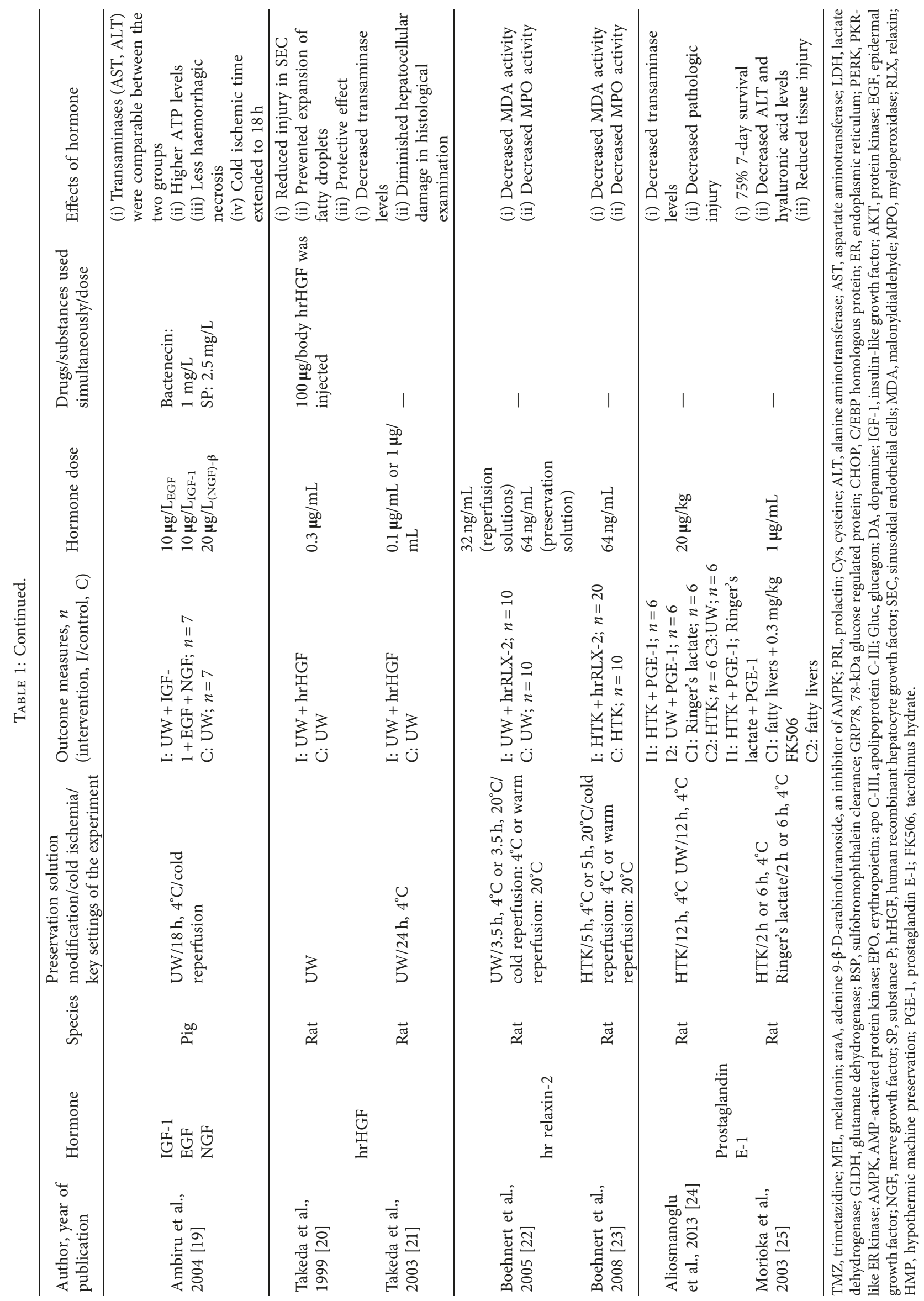


TABLE 2: Composition of preservation solutions.

\begin{tabular}{|c|c|c|c|}
\hline $\begin{array}{l}\text { Component } \\
\text { IC/EX }\end{array}$ & $\begin{array}{l}\text { Viaspan } \\
\text { IC } \\
\end{array}$ & $\begin{array}{l}\text { IGL-1 } \\
\text { EX }\end{array}$ & $\begin{array}{c}\text { HTK } \\
\text { EX }\end{array}$ \\
\hline \multicolumn{4}{|l|}{ Electrolytes $(\mathrm{mmol} / \mathrm{l})$} \\
\hline Potassium & 125 & 25 & 10 \\
\hline Sodium & 29 & 120 & 15 \\
\hline Calcium & - & - & 0.015 \\
\hline Magnesium & 5 & 5 & 4 \\
\hline Chloride & 20 & - & 32 \\
\hline \multicolumn{4}{|l|}{ Colloids (g/L) } \\
\hline HES & 50 & - & - \\
\hline PEG-35 & - & 1 & - \\
\hline \multicolumn{4}{|l|}{ ROS scavengers $(\mathrm{mmol} / \mathrm{l})$} \\
\hline Allopurinol & 1 & 1 & - \\
\hline Glutathione & 3 & 3 & - \\
\hline Mannitol & - & - & 30 \\
\hline Tryptophan & - & - & 2 \\
\hline \multicolumn{4}{|l|}{ Buffers (mmol/l) } \\
\hline Histidine & - & - & 198 \\
\hline $\mathrm{KH}_{2} \mathrm{PO}_{4}$ & 25 & 25 & - \\
\hline \multicolumn{4}{|l|}{ Impermeants (mmol/l) } \\
\hline Lactobionate & 100 & 100 & - \\
\hline Raffinose & 30 & 30 & - \\
\hline \multicolumn{4}{|l|}{ Additives ( $\mathrm{mmol} / \mathrm{l})$} \\
\hline Adenosine & 5 & 5 & - \\
\hline Ketoglutarate & - & - & 1 \\
\hline $\mathrm{pH}$ & 7.4 & 7.4 & 7.2 \\
\hline Viscosity $\left(\mathrm{mm}^{2} / \mathrm{s}\right)$ & 3.16 & 1.25 & 1.00 \\
\hline Osmolality mOsm $/ \mathrm{kg} \mathrm{H}_{2} \mathrm{O}$ & 320 & 290 & 310 \\
\hline
\end{tabular}

IC, intracellular; EX, extracellular.

alanine aminotransferase (ALT) and aspartate aminotransferase (AST), high bile production, and high BSP clearance (sulfobromophthalein (BSP) clearance). There was also increased induction of $\mathrm{NO}$ by activation of constitutive nitric oxide synthase (eNOS) and reduced vascular resistance. Melatonin reduced the mitochondrial oxidative stress and increased the respiratory chain activity [1]. In another publication, Zaouali et al. analysed the effect of melatonin $(100 \mu \mathrm{mol} / \mathrm{L})$ and trimetazidine $(10-3 \mu \mathrm{M} / \mathrm{L})$ addition to the IGL-1 solution in the modulation of ER (endoplasmic reticulum) stress and autophagy in steatotic liver grafts through activation of AMPK. They assessed ER stress (GRP78, PERK, and CHOP) and autophagy (beclin-1, ATG7, LC3B, and P62). They found a significant decrease in GRP78, pPERK, and CHOP activation after reperfusion. The inhibition of AMPK induced an increase in ER stress and a significant reduction in autophagy [2]. Gunal et al. modified the UW solution with melatonin at $130 \mu \mathrm{mol} / \mathrm{L}$. They examined the solution effectiveness in the Wistar rat liver transplantation model. They found that melatonin had a protective effect on Kupffer cells. The amount of enzymes released (LDH, AST, and ACP) was significantly lower compared to the control group. There was also an increase in the expression of heat-shock proteins HSP 70, which play an important role in maintaining normal homeostasis and reducing lipid peroxidation [3]. The research suggests that melatonin at a dose of $100-130 \mu \mathrm{mol} / \mathrm{L}$ is effective as an organ storage solution component and appears to be safe. It improves the vital functions of steatotic livers, which is especially important in the shortage of healthy organs. An important limitation when using melatonin may be its short half-life and interactions resulting from combining melatonin with immunosuppressive drugs (according to the Natural Health Products Directorate). It is suggested that the melatonin bioactivity index over time is higher if it is in the form of nanoparticles (Mel-NPs) [53]. Further research is necessary to optimize solutions with melatonin.

4.2. Prolactin. Prolactin (mammotropin and lactotropin) is a $23 \mathrm{kDa}$ polypeptide hormone, made up of 198 amino acid residues and occurring in three basic isoforms that exhibit immunoreactivity. It is a multifactorial hormone with one of the widest ranges of physiological activities. It stimulates over 300 biological processes occurring in mammalian organisms. It shows endocrine, paracrine, and autocrine activity $[54,55]$. It acts as a cytokine and growth factor, neurotransmitter, immune regulator, regulator of the reproductive cycle, metabolism, and internal homeostasis. It is secreted by the eosinophil cells of the anterior pituitary, ovarian follicular cells, endometrial stromal cells, vascular endothelium cells, temporal membrane, dermal fibroblasts, prostate gland, cerebral cortex, spinal cord, lacrimal gland, sweat gland, thymus, spleen, peripheral blood lymphocytes, and adipocytes [56, 57]. Prolactin receptors are located in most of the body tissues (e.g., in the brain, cerebellum, epithelium of the nipple, liver, kidneys, and lymphocytes), determining the pleiotropic effect of the hormone [58]. Prolactin stimulates proliferation and differentiation of various types of cells (of the immune system, skin, liver, lungs, pancreas, intestines, and prostate) and inhibits apoptosis [59]. It connects with its receptor (PRLr) in the pathway of Jak2, Fyn, and Tec tyrosine kinases, SHP-2 phosphatase, Vav guanine nucleotide exchange factor, and suppressor of cytokine signalling (SOCS) [60]. Prolactin alters the properties of actin cytoskeleton and adhesion of endothelial cell monolayers in a model of mechanical damage to cell culture [61]. It has been found that it is a potent liver mitogen and proangiogenic hormone. It stimulates normal liver growth and regulates its regeneration by lowering IL-6 concentration, regulating SOCS-3 expression (suppressor of cytokine signalling), and increasing hepatocyte proliferation and angiogenesis [62].

Ryszka et al. rinsed isolated rabbit livers with Ringer's solution, which was supplemented with prolactin. The effectiveness of the modified solution was assessed on the basis of biochemical tests. They found that PRL decreased the amount of released alanine aminotransferase (ALT) and aspartate aminotransferase (AST) and slowed down their release rate, which suggests its hepatoprotective properties [4]. The results obtained by Ryszka's team were confirmed by Dolińska et al., who used an isolated porcine liver model to study the effect of prolactin in the HTK solution [5]. The combination of prolactin with cysteine (an antioxidant) in HTK reduced the amount of released transaminases (AST and ALT), lactate dehydrogenase (LDH), and lactic acid. Modification of the solution also resulted in the smaller 
release of $\mathrm{K}^{+}$and $\mathrm{Mg}^{2+}$ ions and larger release of $\mathrm{Na}^{+}$and $\mathrm{Ca}^{2+}$ ions [6]. Szulc-Musioł et al. analysed the pharmacological effectiveness of prolactin in the model of rabbit liver ischemia based on Pringle's manoeuvre. Prolactin at a dose of $100 \mathrm{IU} / \mathrm{L}$ was added to HTK (control test: HTK without prolactin), and the degree of hepatocyte damage was analysed based on the measurement of biochemical parameters (ALT, AST, LDH, GGTP, and lactates) and the histopathological examination of tissues. It was found that, in the livers rinsed with HTK with the addition of PRL, the outflow of enzymes was significantly lower compared to the control group, which suggests that prolactin inhibits the process of liver cell cytolysis [7]. Budziński et al. evaluated the effect of prolactin added to HTK on the degree of hepatocyte apoptosis in an isolated porcine liver model. Apoptosis in the collected tissue samples was assessed by TdT-mediated dUTP nick-labelling. They adopted a prevalence scale ranging from 0 to $3+$, depending on the number of observed nuclei and apoptotic bodies (AB). They found that the addition of prolactin improved the protective properties of HTK, maintaining a high level of apoptosis. Prolactin may influence the stabilization of cell membranes by reducing oncotic necrosis [8]. In another study, using the same research model, Budziński et al. analysed the influence of PRL on the level of catecholamines after 12 hours of liver storage in HTK + PRL and control solutions. The amount of released dopamine and adrenaline significantly decreased after rinsing grafts with HTK modified with the addition of prolactin, which correlates with the degree of ischemic liver injury [9]. The results obtained in the above publications indicate hepatoprotective properties of prolactin.

4.3. Dopamine. Dopamine (molecular mass of $153.181 \mathrm{Da}$ ) inhibits the synthesis and secretion of prolactin by acting on specific type $2\left(D_{2}\right)$ receptors located in the pituitary gland. It is secreted by the hypothalamic neurons, in the region of the tuber cinereum and pituitary stalk (tuberoinfundibular dopaminergic cells-TIDA). It reaches the pituitary eosinophil cells via the pituitary portal circulation. Dopamine (3,4-dihydroxyethylamine) is a neurotransmitter belonging to catecholamines [63]. It shows autocrine and paracrine effects in peripheral tissues [64]. Dopamine receptors are located in the presynaptic and postsynaptic parts of nerve cell membranes, in the kidneys, pancreas, pulmonary alveoli, and the blood vessels of the lungs, kidneys, and heart [65-69]. There are five types of dopamine receptors D1 $\left(D_{1}\right.$ and $\left.\mathrm{D}_{5}\right)$ and $\mathrm{D} 2\left(\mathrm{D}_{2}, \mathrm{D}_{3}\right.$, and $\left.\mathrm{D}_{4}\right)$ [70]. Yard et al. have found that catecholamines protect cells against preservation injury by scavenging reactive oxygen species or by inhibition of reactive oxygen species production [71].

Koetting et al. investigated the efficacy of dopamine in HTK in an ex vivo isolated male Wistar rat liver model. Dopamine was tested at three concentrations of 10,50 , and $100 \mu \mathrm{mol} / \mathrm{L}$. The activities of released ALT, LDH, and GLDH were adopted as liver damage parameters. Liver samples were subjected to histopathological examination. Dopamine induced a dose-related reduction in parenchymal (ALT and LDH) and mitochondrial (GLDH) enzyme release. Bile production and tissue ATP were doubled. The histopathological examination revealed that tissue injury was significantly reduced. The highest effectiveness was obtained for the dopamine dose of $50 \mu \mathrm{mol} / \mathrm{L}$. The least effective dose was $100 \mu \mathrm{mol} / \mathrm{L}$ [10]. Minor et al., based on the model proposed by Koetting [10], used hypothermic machine preservation (HMP) for liver preservation. HTK was equilibrated with $100 \%$ oxygen, and dopamine was added at 10,50 , or $100 \mu \mathrm{mol} / \mathrm{L}$. The livers were flushed via the portal vein and subjected to 20 -hour HMP at $5 \mathrm{ml} / \mathrm{min}$, at $4^{\circ} \mathrm{C}$. No influence of dopamine on vascular resistance, oxygen uptake, or lactate production was found at any concentration. The dopamine dose of $50 \mu \mathrm{mol} / \mathrm{L}$ proved to be optimal. There was a reduced amount of released ALT, increased bile flow, and limited lipid peroxidation (LPO). Dopamine improves functional recovery of livers [11].

4.4. Erythropoietin. Erythropoietin (EPO) is an endogenous hormone with a molecular mass of $34 \mathrm{kDa}$, made up of 165 amino acids. In foetal life, EPO is mainly produced in the liver $(90 \%)$. In postnatal life, it is produced in $80-90 \%$ by periurethral cells and renal cortical fibroblasts and in 10$20 \%$ by hepatocytes and Kupffer cells. Small amounts of EPO are produced in the lungs, brain, testes, placenta, and retina. The physiological concentration of endogenous erythropoietin is $6-32 \mu \mathrm{g} / \mathrm{ml}$ and has a circadian rhythm (the lowest values in the morning hours, the highest at night). Its production depends on the oxygen concentration, which is why its intensive biosynthesis is observed in hypoxemia and anaemia. It is a cytokine with autocrine and paracrine effects. In addition to the stimulation of erythropoiesis in the bone marrow, it also has antioxidant, cytoprotective, pleiotropic, anti-inflammatory, and angiogenic effects. It can regulate glucose metabolism [72-75]. It is believed that it can affect the immune system by lymphocyte activity modulation and pro- and anti-inflammatory cytokine concentration. EPO affects cells via the cytokine receptor, which consists of an extracellular domain, transmembrane domain, and intracellular domain [72]. EPO receptors are located in the kidneys, lungs, pancreas, muscle tissue, neurons, endothelial cells of the blood vessels, fibroblasts, cardiomyocytes, and many carcinomas [76]. Clinical trials indicate that EPO may affect liver regeneration [74], regulate AST activity in the ischemia-reperfusion model [73, 77-80], minimize oxidative stress and caspase-3 activity [81], and reduce nuclear factor- $\mathrm{kB}$ expression [82]. Erythropoietin at a dose of 500-1000 IU/kg body weight [12] has a hepatoprotective effect. Bramey et al., in turn, carried out research on the efficacy of EPO in the model of cultured rat hepatocytes and found that the hormone had no protective effect on cell damage due to hypoxia, reoxygenation, and induced apoptosis [83].

Eipel et al. investigated the effect of the addition of erythropoietin (EPO) to HTK on the functions of steatotic and lean livers in a mouse model. They found that the applied modification minimized the amount of released AST (aspartate aminotransferase), LDH (lactate dehydrogenase), and GLDH (glutamate dehydrogenase) enzymes in steatotic livers up to $50 \%$. In addition, the modified solution 
ameliorated I/R-associated endothelial denudation in steatotic livers. These dependencies were not observed in lean livers. EPO reduced Erk phosphorylation in lean livers. The authors suggest that EPO can increase the effectiveness of marginal liver transplantation. The response of only steatotic livers to EPO may be the result of increased hepatocyte sensitivity to hypoxia and reoxygenation compared to lean livers. EPO in lean livers tends to accentuate tissue damage [12]. The above study does not unambiguously confirm the efficacy of erythropoietin as a component of the HTK solution.

4.5. Insulin. Insulin is a peptide hormone that participates in the metabolism of carbohydrates, lipids, and proteins and mediates the inhibition of their breakdown and release into the bloodstream. It is made up of 51 amino acid residues with a molecular mass of $5.76 \mathrm{kDa}$. Insulin secretion modulates the sympathetic nervous system and catecholamines. This hormone is produced by the beta cells in pancreatic islets of Langerhans containing $\alpha$ - and $\beta$-adrenergic receptors, the activation of which yields opposite effects. Stimulation of $\alpha$-adrenergic receptors inhibits insulin secretion, whereas stimulation of $\beta$-adrenergic receptors stimulates the hormone secretion. Insulin has peripheral effects in skeletal muscle, adipose tissue, and liver cells. It stimulates the uptake of glucose by myocytes, adipocytes, and hepatocytes, inhibits gluconeogenesis, and stimulates glycogenogenesis. It is a strong anabolic hormone, conducive to the storage of metabolic reserves [84-86]. It is suggested that insulin as a component of the UW solution may stimulate the process of glycolysis and liver regeneration [30, 87]. Its administration in donors and recipients improved the graft functions by stimulating energy repletion [88]. The introduction of the hormone into the UW preservation solution is intended to stimulate the production of ATP by glycolysis during liver storage [89].

Li et al. investigated the efficacy of insulin addition to UW in a rat liver transplantation model. Isolated grafts were stored for 24 hours in hypothermia, and then their functions were tested. It was found that the addition of insulin aggravated ischemia-reperfusion injury of the liver, which may affect the inferior graft survival. An increase in the activity of ALT and AST transaminases as well as lower expression of 215 genes was observed [13]. Moreover, the addition of insulin to UW significantly reduced the ATP level, adenine nucleotide pool (TAN), and energy resources of hepatocytes. The glycogenogenesis process and lipoprotein metabolism were accelerated by increased activity of apolipoprotein C-III (Apo C-III) [14]. It can be assumed that the lack of glucose in the UW composition affected the lack of improvement in the energy potential of the liver rinsed with the insulin-enriched solution.

4.6. Glucagon. Glucagon is a polypeptide hormone composed of 29 amino acid residues with a molecular mass of $3.5 \mathrm{kDa}$. The normal plasma glucagon concentration is $50-150 \mathrm{ng} / \mathrm{l}$ [90]. It is secreted by alpha cells of pancreatic islets in response to the low glucose concentration and insulin, somatostatin, and fatty acid levels in the blood. The main task of glucagon is to antagonize the action of insulin. Glucagon is a stimulator of hepatic glycogenolysis, gluconeogenesis, and ketogenesis. It also has inotropic and chronotropic effects independent of the activation of $\beta$-adrenergic receptors [91, 92]. Glucagon action is transduced by the class B G-protein-coupled glucagon receptor (GCGR). Glucagon receptors are found in the kidney, brain, lymphoid cells of the spleen and thymus, parenchymal cells of the liver, and endothelial and Kupffer cells in the liver, heart, adipose tissue, intestinal smooth muscle tissue, and endocrine pancreatic cells $[93,94]$. The attachment of glucagon to a specific receptor on the surface of hepatocytes leads to the activation of adenylyl cyclase, production of cyclic AMP (cAMP), and stimulation of protein kinase A (PKA). PKA, in turn, phosphorylates proteins that contribute to increased hepatic glucose production [95]. Normal cAMP concentration is also an important determinant of the physiological behaviour of the cytoskeleton structure and the maintenance of the physical barrier of endothelial cells [96]. The addition of glucagon to rat liver perfusates may increase cAMP concentration [97].

Minor et al. analysed the effect of glucagon added to UW on hepatocytes in an isolated rat liver model. They have found that the hormone influences the maintenance of the correct structural integrity of hepatocytes (increase in cAMP concentration and decrease in ALT activity), increases bile production in the liver, and regenerates ATP levels in tissues [15].

4.7. Trophic Factors. Hepatic tissue regeneration is possible through hepatocyte proliferative activity. Endogenous hepatic progenitor oval cells with exogenous multipotent bone marrow cells are also involved in this process [98]. Protein growth factors act as regulators of the proliferation process of these cells. They mediate endocrine and paracrine regulation of cell growth and differentiation. Organ perfusion and preservation solutions were modified with the addition of IGF-1 (insulin-like growth factor-1), EGF (epidermal growth factor), NGF (nerve growth factor), and HGF (hepatocyte growth factor).

Insulin-like growth factor-1 (IGF-1) belongs to polypeptide hormones with a molecular mass of $7.65 \mathrm{kDa}$. In terms of structure, it is similar to insulin and relaxin. The IGF1 precursor is found in two isoforms, namely, IGF-1A and IGF-1B. This hormone is characterized by a pleiotropic effect $[99,100]$. Its largest amount was found in liver cells (50-100 times more than in other tissues). IGF-1 produced in the liver has an endocrine effect, whereas the one synthesized in other organs (kidneys, lungs, heart, testes, brain, thyroid, gonads, and large intestine) has an autocrine and/or paracrine effect $[101,102]$. It participates in the regulation of cell differentiation and proliferation. It shows biological activity similar to insulin. It stimulates glucose oxidation and lipogenesis and inhibits lipolysis [103]. It promotes the growth of many body tissues, including postnatal growth, and regulates homeostasis. It stimulates regulatory $\mathrm{T}$ lymphocytes (Treg) to produce anti-inflammatory cytokines (IL-10). IGF-1 interacts 
with the cell by binding to IGF-1R membrane receptors (insulin-like growth factor-1 receptor). This receptor mediates the mitogenic and antiapoptotic activities of IGF-1 and affects cell transformation. This receptor was found inter alia in liver cells (Browicz-Kupffer cells, myofibroblasts, and stellate cells) and cells of the lymphoid organs [104-107]. IGF-1 concentration in blood serum depends on age and gender. Its highest increase is observed during puberty, and it significantly decreases after the age of 25 . In girls aged about 14 years, IGF-1 concentration is $\sim 410 \mu \mathrm{g} / \mathrm{l}$, whereas in boys aged about 15 years IGF- 1 concentration is $\sim 382 \mu \mathrm{g} / \mathrm{l}$. Changes in IGF- 1 concentration depend on the growth hormone concentration [108].

The IGF-1 receptor is essential for the biological activity of the epidermal growth factor (EGF) [109]. EGF stimulates angiogenesis and mitogenesis and regulates the secretion of collagenesis. The EGFR receptor affects biological processes occurring in cells: their growth, differentiation, adhesion, apoptosis, and DNA repair [110]. NGF (nerve growth factor) is in turn a polypeptide with a molecular mass of $26 \mathrm{kDa}$ and belongs to trophic factors (TFs) affecting the population of neurons of the central and peripheral nervous system. The influence of NGF on the immune system (stimulation of the growth and differentiation of $\mathrm{B}$ and $\mathrm{T}$ lymphocytes) and endocrine system (stimulation of the differentiation of pancreatic $\beta$-cells) has been confirmed. NGF affects cells by binding to membrane receptors: NTRK1 and TNFRSF1B $[111,112]$. HGF (hepatocyte growth factor) belongs to the plasminogen proteins and consists of two subunits: the $\alpha$-subunit with a molecular mass of $60 \mathrm{kDa}$ and the $\beta$-subunit with a molecular mass of $30 \mathrm{kDa}$ [113]. It has an autocrine and/or paracrine effect. It is produced by fibroblasts, epithelial and endothelial cells, fat-accumulating cells in the liver, and marrow stromal cells [114]. HGF after binding to the MET receptor is involved in mitogenesis, morphogenesis, cell growth and proliferation, tissue regeneration, inhibition of apoptosis, and repression of intercellular adhesion [115].

Zaouali's team studied the effect of the addition of insulin-like growth factor-1 (IGF-1, $10 \mu \mathrm{g} / \mathrm{l}$ ) on the efficacy of the IGL-1 solution in an isolated rat liver model. They found an increase in the activity of AKT (serine-threonine kinase) and eNOS (endothelial nitric oxide synthase) and inhibition of TNF- $\alpha$ proinflammatory cytokine release [16]. In turn, the addition of the epidermal growth factor (EGF-10 $\mu \mathrm{g} / \mathrm{l}$ ) to the IGL-1 solution in an isolated rat liver model slowed down the release of aminotransferases, increased bile production, and, as a consequence, prevented energy metabolism deterioration, mitochondrial damage, oxidative stress, and cytokine IL-1 beta release [17]. The authors combined the action of IGF-1 and EGF in the UW solution in steatotic and nonsteatotic rat liver models. They found that the addition of EGF and IGF-1 (separately or in combination) to UW reduced hepatic injury and improved function in both liver types. EGF and IGF-I upregulated AKT. AKT protected both liver types, inactivating GSK3 $\beta$ in nonsteatotic livers and inducing PPAR $\gamma$ overexpression in steatotic livers [18]. Ambiru et al. added the trophic factors (TF) to the University of Wisconsin solution. They found that the combination of growth factors (IGF-1, EGF, and NGF) resulted in a significantly better 5-day survival (57\%) compared to using UW alone (14\%). Moreover, ATP content was significantly higher than in grafts preserved in UW. The obtained results indicate that EGF can induce hepatocyte proliferation and increase DNA synthesis in hepatocytes. IGF-1 provides inhibition of apoptosis induced by ischemiareperfusion injury. NGF is related to tissue remodelling in the liver. The absence of trophic factors may cause apoptosis, cell cycle arrest, and cell death [19]. Further studies are necessary to achieve a comprehensive understanding of the system of trophic factors and their receptors. Takeda et al. analysed the effect of human recombinant hepatocyte growth factor (hrHGF) added to UW on the graft function in a rat fatty liver model. They assessed ultrastructural alteration of hepatocytes, sinusoidal architecture, endothelial cells (SECs), hyaluronic uptake rate (HUR), and alanine aminotransferase (ALT) level. The hepatocyte injury and SECs developed more rapidly than in the control solution, i.e., UW. The results obtained suggest hepatoprotective effects of hrHGF [20, 21].

4.8. Relaxin. Relaxin is a polypeptide hormone with a molecular mass of $6 \mathrm{kDa}$ and a structure similar to insulin and insulin-like growth factor. However, it does not activate insulin receptors and has a different multidirectional effect on tissues. It interacts through the endocrine, paracrine, and autocrine pathways. Relaxin-2 is present in the ovaries, uterus, testes, prostate gland, brain, cardiovascular system, skin, lungs, liver, and kidneys [116, 117]. It activates the LGR7 and LGR8 receptors belonging to the transmembrane receptors, coupled to the $G$ protein. It participates in cell proliferation and differentiation. It relaxes the walls of blood vessels as a result of stimulation of nitric oxide production in endothelial cells. It has cytoprotective and anti-inflammatory effects. It inhibits fibrosis processes in damaged organs (including the liver) by activating metalloproteinases [118-121].

Boehnert et al. analysed the efficacy of relaxin in an isolated perfused rat liver model. Relaxin was added to the UW [22] and HTK [23] solutions and its effect during graft preservation and reperfusion was studied. They found a protective effect of relaxin. The activity of malonyldialdehyde (MDA, end product of lipid peroxidation) and myeloperoxidase (MPO, marker for accumulation of neutrophil granulocytes) was lower compared to the control group. Relaxin affects decreased peroxidation and increased oxygen.

4.9. Prostaglandin E1. Prostaglandin E-1 (PGE-1) has a molecular mass of $354.48 \mathrm{Da}$. It belongs to paracrine hormones that have high biological activity. It is formed from arachidonic acid in the cyclooxygenase process. It is found in all tissues, organs, and body fluids, except for red blood cells. It exhibits a short half-life, which is why it usually acts locally. It takes part in the regulation of homeostasis. It has a relaxant effect on smooth muscles, especially the ductus arteriosus muscles [122]. It stimulates the activity of adenylyl 
cyclase in platelets. It demonstrates the ability to bind to cell surface receptors increasing the concentration of cAMP (cyclic adenosine monophosphate), which is involved in the regulation of biochemical processes as an element of signal transduction. In addition, it inhibits the release of $\mathrm{Ca}^{2+}$ ions [123]. Stellate cells of the liver under the influence of prostaglandins have the ability to relax causing diastole [124]. PGE-1 secretion in Kupffer cells in response to ischemia/reperfusion has been detected [125]. As a result of the release of growth factors, TNF- $\alpha$ and prostaglandins, appropriate receptors are activated on the surface of hepatocytes, and proliferation of these cells is increased through the NF- $\kappa B$ pathway [126]. It has been found that PGE-1 has a cytoprotective, regenerative effect, increases the liver perfusion, inhibits platelet aggregation and protease, and minimizes the production of free oxygen radicals $[127,128]$.

Aliosmanoglu et al. studied the effect of prostaglandin E-1 (PGE-1) on the damage of rat livers perfused with the University of Wisconsin (UW) solution or the histidine-tryptophan-ketoglutaric solution (HTK). The authors assessed the biochemical and histopathological parameters of the perfusates and tissues collected. They stated that PGE-1 improved the activity of grafts. Cell damage was smaller compared to the other test groups [24]. Morioka et al. [25] added PGE-1 at a dose of $1 \mu \mathrm{g} / \mathrm{mL}$ to the composition of HTK and Ringer's lactate. The solution effectiveness was analysed based on a rat fatty liver model. The hormone improved the rate of graft survival (75\% 7-day survival) and decreased ALT activity and hyaluronic acid concentration. The results obtained in the above studies indicate the protective effect of PGE-1 during ischemia/reperfusion of the liver. The hormone improves the vital functions of rat fatty livers.

\section{Barriers to Clinical Trials}

The studies on the effectiveness of commercial hormonemodified preservation solutions presented in the review have been performed in animal models, representatives of the mammal group. In the available literature, there was no information on completed or ongoing clinical trials on this subject until May 31, 2019. We suggest that there are several reasons that may constitute a barrier to these tests. Liver donors are people of a wide age range (from children to the elderly), in whom the occurrence of comorbidities increases with age. In the animal models, healthy/young animals or mammals with induced liver disease (steatotic liver model) were selected for testing, which is difficult to refer to acquired human livers. Species differences in liver anatomical structure should also be taken into account. The most similar in terms of size and physiologically similar to human livers are organs derived from domestic pigs, which were used in the model of prolactin $[5,6,8,9]$ and IGF-1/EGF/NGF efficacy [19]. The effects of hormone administration in vivo depend not only on the mammalian species, but also on its sex, age, biopharmaceutical dose and dosage form, time of day and season of its administration, and time of use [129]. The proposed hormone doses were not optimized in most studies. Only in some studies, in which the effect of biopharmaceutical concentration on the effectiveness of the modified solution was analysed, it was found that the increase in hormone concentration did not correlate with its higher efficiency $[10,11]$. The possible interactions between components of preservation solutions and hormones should also be considered. Each, even the smallest change in the chemical structure and physicochemical properties of the substances included in the solution affects its effectiveness. Hormones may also interact with pharmaceutical preparations used in recipients during and after liver transplantation (e.g., immunosuppressants). In addition, they may affect the transplanted liver function in the long term (the performed studies were short term) [130].

\section{Conclusion}

Based on the performed analyses on the effectiveness of hormone-modified organ perfusion and preservation solutions, it can be concluded that it is possible to develop new fluid formulations that enable to preserve or improve vital functions of the liver, including marginal grafts. Further research in this direction is still necessary. It will allow to get to know the mechanism of action of these substances on the liver and develop new, prospective solutions protecting the organ during ischemia/reperfusion. It will also allow for the development of effective systemic therapy with limited side effects.

A great challenge and future for commercial preservation solutions containing biopharmaceuticals is the development of a formulation with optimal pharmacokinetics and hormone biodistribution, focused on high effectiveness in minimizing ischemic-reperfusion injury. Ensuring adequate physicochemical stability of the solution during its storage and use is also an extremely important element. The possibility of using hormone analogues with a prolonged halflife seems to be promising. A particularly interesting strategy is the use of hormones in the form of nanocarriers, which could affect the kinetics of their release (obtaining fast and/ or prolonged or controlled action), increase physicochemical stability, ensure delivery to a specific site of action, and minimize the risk of interactions. Potential hormone delivery systems may be nanoemulsions, liposomes, and polymer micelles. They allow to increase biopharmaceutical bioavailability and show the ability for selective accumulation and retention in tissue for a long time.

Due to security issues, which are the priority when implementing new techniques into therapeutic regimens, it is important to analyse the long-term effect of the hormone dosage form on the recipient's liver/body.

\section{Conflicts of Interest}

The authors declare that there are no conflicts of interest regarding the publication of this article.

\section{Acknowledgments}

This work was supported by the Medical University of Silesia in Katowice through Grant no. KNW-1-034/N/9/O. The authors would like to express very special thanks to Prof. 
Florian Ryszka for her inspiration and valuable comments on this manuscript.

\section{References}

[1] M. A. Zaoualí, R. J. Reiter, S. Padrissa-Altés et al., "Melatonin protects steatotic and nonsteatotic liver grafts against cold ischemia and reperfusion injury," Journal of Pineal Research, vol. 50, no. 2, pp. 213-221, 2011.

[2] M. A. Zaouali, E. Boncompagni, R. J. Reiter et al., “AMPK involvement in endoplasmic reticulum stress and autophagy modulation after fatty liver graft preservation: a role for melatonin and trimetazidine cocktail," Journal of Pineal Research, vol. 55, no. 1, pp. 65-78, 2013.

[3] O. Gunal, A. Cokun, A. Aslaner, and U. Yildirim, "Does melatonin alleviate cold preservation injury of the liver?," Turkish Journal of Medical Sciences, vol. 40, no. 3, pp. 465470, 2010.

[4] F. Ryszka, B. Dolińska, M. Sławski, and W. Orkisz, "Effect of prolactin on release of selected enzymes from the isolated rabbit liver," Transplantation Proceedings, vol. 36, no. 9, pp. 2583-2585, 2004.

[5] B. Dolinska, G. Budzinski, A. Caban et al., "Prolactin (PRL) reduces the release of transaminases from the isolated pig liver," Annals of Transplantation, vol. 16, no. 2, pp. 98-102, 2011.

[6] F. Ryszka, B. Dolińska, A. Caban et al., "Hepatoprotective effect of prolactin and cysteine contained in perfusion and preservation solutions on porcine liver stored in simple hypothermia," Transplantation Proceedings, vol. 43, no. 8, pp. 2882-2886, 2011.

[7] B. Szulc-Musioł, B. Dolińska, K. Jasik, and F. Ryszka, "Effect of prolactin on biochemical and morphological parameters of rabbit liver in warm ischemia," Transplantation Proceedings, vol. 50, no. 7, pp. 2229-2234, 2018.

[8] G. Budziński, R. Wiaderkiewicz, A. Caban et al., "Evaluation of apoptosis in the liver preserved by simple hypothermia using histidine-tryptophan-ketoglutarate and prolactinmodified histidine-tryptophan-ketoglutarate solution," Transplantation Proceedings, vol. 43, no. 8, pp. 2900-2902, 2011.

[9] G. Budziński, A. Suszka-Świtek, R. Dec et al., "Adrenaline and dopamine in porcine livers after cold preservation with University of Wisconsin histidine-tryptophan-ketoglutarate, prolactin-modified histidine-tryptophan-ketoglutarate solutions," Transplantation Proceedings, vol. 43, no. 8, pp. 2895-2896, 2011.

[10] M. Koetting, J. Stegemann, and T. Minor, "Dopamine as additive to cold preservation solution improves postischemic integrity of the liver," Transplant International, vol. 23, no. 9, pp. 951-958, 2010.

[11] T. Minor, B. Lüer, and P. Efferz, "Dopamine improves hypothermic machine preservation of the liver," Cryobiology, vol. 63, no. 2, pp. 84-89, 2011.

[12] C. Eipel, U. Hübschmann, K. Abshagen, K. F. Wagner, M. D. Menger, and B. Vollmar, "Erythropoietin as additive of HTK preservation solution in cold ischemia/reperfusion injury of steatotic livers," Journal of Surgical Research, vol. 173, no. 1, pp. 171-179, 2012.

[13] X.-L. Li, K. Man, Y.-F. Liu et al., "Insulin in University of Wisconsin solution exacerbates the ischemic injury and decreases the graft survival rate in rat liver transplantation," Transplantation, vol. 76, no. 1, pp. 44-49, 2003.
[14] X. L. Li, K. Man, K. T. Ng, T. K. Lee, C. M. Lo, and S. T. Fan, "Insulin in UW solution exacerbates hepatic ischemia/ reperfusion injury by energy depletion through the IRS-2/ SREBP-1c pathway," Liver Transplantation, vol. 10, no. 9, pp. 1173-1182, 2004.

[15] T. Minor and S. Akbar, "Enhancement of endogenous cyclic amp signal,” Transplantation, vol. 66, no. 8, pp. 990-994, 1998.

[16] M. A. Zaouali, S. Padrissa-Altés, I. Ben Mosbah et al., "Insulin like growth factor-1 increases fatty liver preservation in IGL-1 solution," World Journal of Gastroenterology, vol. 16, no. 45, pp. 5693-5700, 2010.

[17] M. A. Zaouali, I. Ben Mosbah, S. Padrissa-Altés et al., "Relevance of epidermal growth factor to improve steatotic liver preservation in IGL-1 solution," Transplantation Proceedings, vol. 42, no. 8, pp. 3070-3075, 2010.

[18] M. A. Zaouali, S. Padrissa-Altés, I. Ben Mosbah et al., "Improved rat steatotic and nonsteatotic liver preservation by the addition of epidermal growth factor and insulin-like growth factor-I to University of Wisconsin solution," Liver Transplantation, vol. 16, no. 9, pp. 1098-1111, 2010.

[19] S. Ambiru, K. Uryuhara, S. P. Talpe et al., "Improved survival of orthotopic liver allograft in swine by addition of trophic factors to University of Wisconsin solution," Transplantation, vol. 77, no. 2, pp. 302-304, 2004.

[20] Y. Takeda, S. Arii, T. Kaido et al., "Morphologic alteration of hepatocytes and sinusoidal endothelial cells in rat fatty liver during cold preservation and the protective effect of hepatocyte growth factor," Transplantation, vol. 67, no. 6, pp. 820-828, 1999.

[21] Y. Takeda, S. Arii, T. Kaido, and M. Imamura, "The impairment of hepatocytes and sinusoidal endothelial cells during cold preservation in rat fatty liver induced by alcohol and the beneficial effect of hepatocyte growth factor," Transplant International, vol. 16, no. 4, pp. 241-249, 2003.

[22] M. U. Boehnert, H. Hilbig, and F. P. Armbruster, "Relaxin as an additional protective substance in preserving and reperfusion solution for liver transplantation, shown in a model of isolated perfused rat liver," Annals of the New York Academy of Sciences, vol. 1041, no. 1, pp. 434-440, 2005.

[23] M. U. Boehnert, F. P. Armbruster, and H. Hilbig, "Relaxin as a protective substance in preservation solutions for organ transplantation, as shown in an isolated perfused rat liver model," Transplantation Proceedings, vol. 40, no. 4, pp. 978-980, 2008.

[24] I. Aliosmanoglu, S. Sevmis, H. Karakayali et al., "Effect of prostaglandin E-1 on Wisconsin University and histidinetryptophan-ketoglutarate preservation solutions on preservation injury of the perfused liver," Transplantation Proceedings, vol. 45, no. 6, pp. 2446-2450, 2013.

[25] D. Morioka, T. Kubota, H. Sekido et al., "Prostaglandin E1 improved the function of transplanted fatty liver in a rat reduced-size-liver transplantation model under conditions of permissible cold preservation," Liver Transplantation, vol. 9, no. 1, pp. 79-86, 2003.

[26] M. Selzner, H. A. RüDiger, D. Sindram, J. Madden, and P.-A. Clavien, "Mechanisms of ischemic injury are different in the steatotic and normal rat liver," Hepatology, vol. 32, no. 6, pp. 1280-1288, 2000.

[27] F. S. Ramalho, I. Fernandez-Monteiro, J. Rosello-Catafau, and C. Peralta, "Hepatic microcirculatory failure," Acta Cirúrgica Brasileira, vol. 21, no. 1, pp. 48-53, 2006.

[28] A. Serafín, J. Roselló-Catafau, N. Prats, E. Gelpí, J. Rodés, and C. Peralta, "Ischemic preconditioning affects interleukin 
release in fatty livers of rats undergoing ischemia/reperfusion," Hepatology, vol. 39, no. 3, pp. 688-698, 2004.

[29] I. H. Straatsburg, S. L. Abrahamse, S. W. Song, R. J. Hartman, and T. M. Van Gulik, "Evaluation of rat liver apoptotic and necrotic cell death after cold storage using UW, HTK, and celsior," Transplantation, vol. 74, no. 4, pp. 458-464, 2002.

[30] A. B. Quintana, E. E. Guibert, and J. V. Rodríguez, "Effect of cold preservation/reperfusion on glycogen content of liver. Concise review," Annals of Hepatology, vol. 4, no. 1, pp. 25-31, 2005.

[31] R. Adam, V. Delvart, V. Karam et al., "Compared efficacy of preservation solutions in liver transplantation: a long-term graft outcome study from the European liver transplant registry," American Journal of Transplantation, vol. 15, no. 2, pp. 395-406, 2015.

[32] I. Ben Mosbah, J. Roselló-Catafau, R. Franco-Gou et al., "Preservation of steatotic livers in IGL-1 solution," Liver Transplantation, vol. 12, no. 8, pp. 1215-1223, 2006.

[33] T. Ugurlu, C. Ozogul, G. S. Saribas, S. G. Gurgen, S. N. Akyol, and B. Kartal, "The effect of antioxidants on angiogenesis in uterine transplantation," Journal of Obstetrics and Gynaecology, vol. 38, no. 3, pp. 382-387, 2018.

[34] J. A. Fridell, R. S. Mangus, and J. A. Powelson, "Organ preservation solutions for whole organ pancreas transplantation," Current Opinion in Organ Transplantation, vol. 16, no. 1, pp. 116-122, 2011.

[35] E. E. Benarroch, "Suprachiasmatic nucleus and melatonin: reciprocal interactions and clinical correlations," Neurology, vol. 71, no. 8, pp. 594-598, 2008.

[36] S. R. Pandi-Perumal, V. Srinivasan, G. J. M. Maestroni, D. P. Cardinali, B. Poeggeler, and R. Hardeland, "Melatonin,” FEBS Journal, vol. 273, no. 13, pp. 2813-2838, 2006.

[37] B. Jung and N. Ahmad, "Melatonin in cancer management: progress and promise: figure 1," Cancer Research, vol. 66, no. 20, pp. 9789-9793, 2006.

[38] D.-X. Tan, L. C. Manchester, R. J. Reiter, W. Qi, M. A. Hanes, and N. J. Farley, "High physiological levels of melatonin in the bile of mammals," Life Sciences, vol. 65, no. 23, pp. 2523-2529, 1999.

[39] M. Messner, G. Huether, T. Lorf, G. Ramadori, and H. Schwörer, "Presence of melatonin in the human hepatobiliary-gastrointestinal tract," Life Sciences, vol. 69, no. 5, pp. 543-551, 2001.

[40] G. A. Bubenik, "Thirty years since the discovery of gastrointestinal melatonin," Journal of Physiology and Pharmacology, vol. 59, pp. 33-51, 2008.

[41] R. J. Reiter, D. X. Tan, L. C. Manchester, M. Pilar-Terron, L. J. Flores, and S. Koppisepi, "Medical implications of melatonin: receptor-mediated and receptor-independent action," Advances in Medical Sciences, vol. 52, pp. 11-28, 2007.

[42] R. Jockers, P. Maurice, J. A. Boutin, and P. Delagrange, "Melatonin receptors, heterodimerization, signal transduction and binding sites: what's new?," British Journal of Pharmacology, vol. 154, no. 6, pp. 1182-1195, 2008.

[43] M. M. Macchi and J. N. Bruce, "Human pineal physiology and functional significance of melatonin," Frontiers in Neuroendocrinology, vol. 25, no. 3-4, pp. 177-195, 2004.

[44] P. Sallinen, S. Saarela, M. Ilves, O. Vakkuri, and J. Leppäluoto, "The expression of MT1 and MT2 melatonin receptor mRNA in several rat tissues," Life Sciences, vol. 76, no. 10, pp. 1123-1134, 2005.

[45] A. N. Smirnov, "Nuclear melatonin receptors," Biochemistry, vol. 66, no. 1, pp. 19-26, 2001.
[46] D. Acuña-Castroviejo, R. J. Reiter, A. Menendez-Pelaez, M. I. Pablos, and A. Burgos, "Characterization of high-affinity melatonin binding sites in purified cell nuclei of rat liver," Journal of Pineal Research, vol. 16, no. 2, pp. 100-112, 1994.

[47] P. Dzięgiel, M. Podhorska-Okołów, and M. Zabel, "Melatonin: adjuvant therapy of malignant tumors," Medical Science Monitor, vol. 14, no. 5, pp. RA64-RA70, 2008.

[48] D. X. Tan, L. C. Manchester, R. J. Reiter, W. B. Qi, M. Karbownik, and J. R. Calvo, "Significance of melatonin in antioxidative defense system: reactions and products," Biological Signals and Receptors, vol. 9, no. 3-4, pp. 137-159, 2000.

[49] K. Pugazhenthi, M. Kapoor, A. N. Clarkson, I. Hall, and I. Appleton, "Melatonin accelerates the process of wound repair in full-thickness incisional wounds," Journal of Pineal Research, vol. 44, no. 4, pp. 387-396, 2008.

[50] R. J. Reiter, J. R. Calvo, M. Karbownik, W. Qi, and D. X. Tan, "Melatonin and its relation to the immune system and inflammation," Annals of the New York Academy of Sciences, vol. 917, pp. 376-386, 2000.

[51] E. Gitto, D.-X. Tan, R. J. Reiter et al., "Individual and synergistic antioxidative actions of melatonin: studies with vitamin E, vitamin C, glutathione and desferrrioxamine (desferoxamine) in rat liver homogenates," Journal of Pharmacy and Pharmacology, vol. 53, no. 10, pp. 1393-1401, 2001.

[52] S. López-Burillo, D.-X. Tan, J. C. Mayo, R. M. Sainz, L. C. Manchester, and R. J. Reiter, "Melatonin, xanthurenic acid, resveratrol, EGCG, vitamin $\mathrm{C}$ and $\alpha$-lipoic acid differentially reduce oxidative DNA damage induced by Fenton reagents: a study of their individual and synergistic actions," Journal of Pineal Research, vol. 34, no. 4, pp. 269-277, 2003.

[53] Q. Ma, J. Yang, X. Huang et al., "Poly(lactide-co-glycolide)monomethoxy-poly-(polyethylene glycol) nanoparticles loaded with melatonin protect adipose-derived stem cells transplanted in infarcted heart tissue," Stem Cells, vol. 36, no. 4, pp. 540-550, 2018.

[54] V. Goffin, N. Binart, P. Touraine, and P. A. Kelly, "Prolactin: the new biology of an old hormone," Annual Review of Physiology, vol. 64, no. 1, pp. 47-67, 2002.

[55] R. J. Marano and N. Ben-Jonathan, "Minireview: extrapituitary prolactin: an update on the distribution, regulation, and functions," Molecular Endocrinology, vol. 28, no. 5, pp. 622-633, 2014.

[56] S. Gerlo, J. R. E. Davis, D. L. Mager, and R. Kooijman, "Prolactin in man: a tale of two promoters," Bioessays, vol. 28, no. 10, pp. 1051-1055, 2006.

[57] N. Ben-Jonathan, J. L. Mershon, D. L. Allen, and R. W. Steinmetz, "Extrapituitary prolactin: distribution, regulation, functions, and clinical aspects," Endocrine Reviews, vol. 17, no. 6, pp. 639-669, 1996.

[58] P. A. Abramicheva and O. V. Smirnova, "Prolactin receptor isoforms as the basis of tissue-specific action of prolactin in the norm and pathology," Biochemistry (Moscow), vol. 84, no. 4, pp. 329-345, 2019.

[59] O. Vera-Lastra, L. J. Jara, and L. R. Espinoza, "Prolactin and autoimmunity," Autoimmunity Reviews, vol. 1, no. 6, pp. 360-364, 2002.

[60] C. V. Clevenger and J. B. Kline, "Prolactin receptor signal transduction," Lupus, vol. 10, no. 10, pp. 706-718, 2001.

[61] C. J. Merkle, L. A. Schuler, R. C. Schaeffer Jr., J. M. Gribbon, and D. W. Montgomery, "Structural and functional effects of high prolactin levels on injured endothelial cells: evidence for 
an endothelial prolactin receptor," Endocrine, vol. 13, no. 1, pp. 37-46, 2000.

[62] B. Moreno-Carranza, M. Goya-Arce, C. Vega et al., "Prolactin promotes normal liver growth, survival, and regeneration in rodents: effects on hepatic IL-6, suppressor of cytokine signaling-3, and angiogenesis," American Journal of Physiology-Regulatory, Integrative and Comparative Physiology, vol. 305, no. 7, pp. R720-R726, 2013.

[63] N. D. Horseman, "Prolactin," in Endocrinology, pp. 209-220, WB Saunders, Philadelphia, PA, USA, 2001.

[64] T. Hussain and M. F. Lokhandwala, "Renal dopamine receptors and hypertension," Experimental Biology and Medicine, vol. 228, no. 2, pp. 134-142, 2003.

[65] C. Bergson, R. Levenson, P. S. Goldman-Rakic, and M. S. Lidow, "Dopamine receptor-interacting proteins: the $\mathrm{Ca} 2+$ connection in dopamine signaling," Trends in Pharmacological Sciences, vol. 24, no. 9, pp. 486-492, 2003.

[66] T. Huo and D. P. Healy, "Autoradiographic localization of dopamine DA1 receptors in rat kidney with [3H]Sch 23390," American Journal of Physiology-Renal Physiology, vol. 257, no. 3, pp. F414-F423, 1989.

[67] E. Mezey, G. Eisenhofer, G. Harta et al., "A novel nonneuronal catecholaminergic system: exocrine pancreas synthesizes and releases dopamine," Proceedings of the $\mathrm{Na}$ tional Academy of Sciences, vol. 93, no. 19, pp. 10377-10382, 1996.

[68] M. L. Barnard, K. M. Ridge, F. Saldias et al., "Stimulation of the dopamine 1 receptor increases lung edema clearance," American Journal of Respiratory and Critical Care Medicine, vol. 160, no. 3, pp. 982-986, 1999.

[69] P. Cheung and K. J. Barrington, "Renal dopamine receptors: mechanisms of action and developmental aspects," Cardiovascular Research, vol. 31, no. 1, pp. 2-6, 1996.

[70] D. Vallone, R. Picetti, and E. Borrelli, "Structure and function of dopamine receptors," Neuroscience and Biobehavioral Reviews, vol. 24, no. 1, pp. 125-132, 2000.

[71] B. Yard, G. Beck, P. Schnuelle et al., "Prevention of coldpreservation injury of cultured endothelial cells by catecholamines and related compounds," American Journal of Transplantation, vol. 4, no. 1, pp. 22-30, 2004.

[72] M. Lombardero, K. Kovacs, and B. W. Scheithauer, "Erythropoietin: a hormone with multiple functions," Pathobiology, vol. 78, no. 1, pp. 41-53, 2011.

[73] K. A. Lisowska, E. Bryl, and J. M. Witkowski, "The influence of recombinant human erythropoietin on the immune system," Forum Medycyny Rodzinnej, vol. 3, no. 5, pp. 359-366, 2009.

[74] R. Meng, D. Zhu, Y. Bi, D. Yang, and Y. Wang, "Erythropoietin inhibits gluconeogenesis and inflammation in the liver and improves glucose intolerance in high-fat diet-fed mice," PLoS One, vol. 8, no. 1, Article ID e53557, 2013.

[75] L. Kebschull, L. F. C. Theilmann, A. Mohr et al., "EPOR2/ $\beta c R 2$-independendent effects of low-dose epoetin- $\alpha$ in porcine liver transplantation," Bioscience Reports, vol. 37, no. 6, Article ID BSR20171007, 2017.

[76] M. Gul, M. Cömert, G. K. Çakmak, G. Kertis, E. Ugurbas, and M. O. Oner, "Effect of erythropoietin on liver regeneration in an experimental model of partial hepatectomy," International Journal of Surgery, vol. 11, no. 1, pp. 59-63, 2013.

[77] P. van der Meer, A. A. Voors, E. Lipsic, W. H. van Gilst, and D. J. van Veldhuisen, "Erythropoietin in cardiovascular diseases," European Heart Journal, vol. 25, no. 4, pp. 285291, 2004.
[78] W. Fu, X. Liao, J. Ruan et al., "Recombinant human erythropoietin preconditioning attenuates liver ischemia reperfusion injury through the phosphatidylinositol-3 kinase/AKT/endothelial nitric oxide synthase pathway," Journal of Surgical Research, vol. 183, no. 2, pp. 876-884, 2013.

[79] M. Kato, T. Sawada, J. Kita, M. Shimoda, and K. Kubota, "Erythropoietin ameliorates early ischemia-reperfusion injury following the Pringle maneuver," World Journal of Gastroenterology, vol. 16, no. 38, pp. 4838-4845, 2010.

[80] C. Tsompos, C. Panoulis, and K. Toutouzas, "The effect of erythropoietin on aspartate aminotransferase levels during ischemia reperfusion injury in rats," Electronic Journal of Biology, vol. 12, p. 2, 2016.

[81] B. Sepodes, R. Maio, R. Pinto et al., "Recombinant human erythropoietin protects the liver from hepatic ischemiareperfusion injury in the rat," Transplant International, vol. 19, no. 11, pp. 919-926, 2006.

[82] O. Pappo, Z. Ben-Ari, E. Shevtsov et al., "The role of excessive versus acute administration of erythropoietin in attenuating hepatic ischemia-reperfusion injury," Canadian Journal of Physiology and Pharmacology, vol. 88, no. 12, pp. 1130-1137, 2010.

[83] T. Bramey, P. Freitag, J. Fandrey et al., "No evidence for protective erythropoietin $\alpha$ signaling in rat hepatocytes," BMC Gastroenterology, vol. 9, no. 26, p. 26, 2009.

[84] P. M. Dubois, "Ontogeny of the endocrine pancreas," Hormone Research, vol. 32, no. 1-3, pp. 53-60, 1989.

[85] S. M. Najjar and G. Perdomo, "Hepatic insulin clearance: mechanism and physiology," Physiology, vol. 34, no. 3, pp. 198-215, 2019.

[86] Z. Fu, E. R. Gilbert, and D. Liu, "Regulation of insulin synthesis and secretion and pancreatic Beta-cell dysfunction in diabetes," Current Diabetes Reviews, vol. 9, no. 1, pp. 25-53, 2013.

[87] M. Marino, M. T. Mangiantini, S. Spagnuolo, P. Luly, and S. Leoni, "Signal transduction during liver regeneration: role of insulin and vasopressin," Journal of Cellular Physiology, vol. 152, no. 2, pp. 403-409, 1992.

[88] Y. Morimoto, W. Kamiike, T. Nishida et al., "Improvement of rat liver graft function by insulin administration to donor," Gastroenterology, vol. 111, no. 4, pp. 1071-1080, 1996.

[89] J. J. Lemasters, H. Bunzendahl, and R. G. Thurman, "Preservation of the liver," in Transplantation of the Liver, p. 254, Lippincott Williams \& Wilkins, Philadelphia, PA, USA, 2001.

[90] N. Taleb, A. Haidar, V. Messier, V. Gingras, L. Legault, and R. Rabasa-Lhoret, "Glucagon in artificial pancreas systems: potential benefits and safety profile of future chronic use," Diabetes, Obesity and Metabolism, vol. 19, no. 1, pp. 13-23, 2017.

[91] L. Jelinek, S. Lok, G. Rosenberg et al., "Expression cloning and signaling properties of the rat glucagon receptor," Science, vol. 259, no. 5101, pp. 1614-1616, 1993.

[92] C. M. White, "A review of potential cardiovascular uses of intravenous glucagon administration," The Journal of Clinical Pharmacology, vol. 39, no. 5, pp. 442-447, 1999.

[93] A. Jazayeri, A. S. Doré, D. Lamb et al., "Extra-helical binding site of a glucagon receptor antagonist," Nature, vol. 533, no. 7602, pp. 274-277, 2016.

[94] M. Watanabe, H. Hayasaki, T. Tamayama, and M. Shimada, "Histologic distribution of insulin and glucagon receptors," Brazilian Journal of Medical and Biological Research, vol. 31, no. 2, pp. 243-256, 1998. 
[95] K. Nabrdalik, E. Cichocka, and J. Gumprecht, "Metformin and AMP-activated protein kinase and energetic processes," Diabetologia Kliniczna, vol. 2, no. 4, pp. 125-130, 2013.

[96] T. J. Stelzner, J. V. Weil, and R. F. O’Brien, "Role of cyclic adenosine monophosphate in the induction of endothelial barrier properties," Journal of Cellular Physiology, vol. 139, no. 1, pp. 157-166, 1989.

[97] J. Kuster, J. Zapf, and A. Jakob, "Effects of hormones on cyclic AMP release in perfused rat livers," FEBS Letters, vol. 32, no. 1, pp. 73-77, 1973.

[98] S. Sell, "Heterogeneity and plasticity of hepatocyte lineage cells," Hepatology, vol. 33, no. 3, pp. 738-750, 2001.

[99] D. Le Roith, C. Bondy, S. Yakar, J. L. Liu, and A. Butler, "The somatomedin hypothesis: 2001," Endocrine Reviews, vol. 22, no. 1, pp. 53-74, 2001.

[100] E. R. Barton, "The ABCs of IGF-I isoforms: impact on muscle hypertrophy and implications for repair," Applied Physiology, Nutrition, and Metabolism, vol. 31, no. 6, pp. 791-797, 2006.

[101] A. J. D’Ercole, A. D. Stiles, and L. E. Underwood, “Tissue concentration of somatomedin C: further evidence for multiple sites of synthesis and paracrine or autocrine mechanisms of action," Proceedings of the National Academy of Sciences of the United States of America, vol. 81, no. 3, pp. 935-939, 1984.

[102] H. M. Khandwala, I. E. McCutcheon, A. Flyvbjerg, and K. E. Friend, "The effects of insulin-like growth factors on tumorigenesis and neoplastic growth," Endocrine Reviews, vol. 21, no. 3, pp. 215-244, 2000.

[103] W. H. Daughday and P. Rotweien, "Insulin-like growth factors I and II. peptide, messenger ribonucleic acid and gene structures, serum and tissue concentrations," Endocrine Reviews, vol. 10, no. 1, pp. 68-91, 1989.

[104] G. Vassilakos, A. Philippou, P. Tsakiroglou, and M. Koutsilieris, "Biological activity of the e domain of the IGF-1Ec as addressed by synthetic peptides," Hormones, vol. 13, no. 2, pp. 182-196, 2014.

[105] A. Obrępalska-Stęplowska, Ł. Durzyński, and A. GoździckaJózefiak, "Insulin-like growth factor and interacting proteins," Postępy Biochemii, vol. 51, no. 1, pp. 69-79, 2005.

[106] D. A. Weigent, "Lymphocyte GH-axis hormones in immunity," Cellular Immunology, vol. 285, no. 1-2, pp. 118-132, 2013.

[107] J.-G. Scharf, F. Dombrowski, and G. Ramadori, “The IGF axis and hepatocarcinogenesis," Molecular Pathology, vol. 54, no. 3, pp. 138-144, 2001.

[108] A. Juul, P. Bang, N. T. Hertel et al., "Serum insulin-like growth factor-I in 1030 healthy children, adolescents, and adults: relation to age, sex, stage of puberty, testicular size, and body mass index," The Journal of Clinical Endocrinology and Metabolism, vol. 78, no. 3, pp. 744-752, 1994.

[109] T. Deangelis, A. Ferber, and R. Baserga, "Insulin-like growth factor I receptor is required for the mitogenic and transforming activities of the platelet-derived growth factor receptor," Journal of Cellular Physiology, vol. 164, no. 1, pp. 214-221, 1995.

[110] J. Zhang, N. F. Saba, G. Chen, and D. M. Shin, "Targeting HER (ERBB) signaling in head and neck cancer: an essential update," Molecular Aspects of Medicine, vol. 45, pp. 74-86, 2015.

[111] U. Otten, P. Ehrhard, and R. Peck, "Nerve growth factor induces growth and differentiation of human B lymphocytes," Proceedings of the National Academy of Sciences, vol. 86, no. 24, pp. 10059-10063, 1989.
[112] M. Polak, R. Scharfmann, B. Seilheimer et al., "Nerve growth factor induces neuron-like differentiation of an insulin-secreting pancreatic beta cell line," Proceedings of the National Academy of Sciences, vol. 90, no. 12, pp. 5781-5785, 1993.

[113] L. Trusolino and P. M. Comoglio, "Scatter-factor and semaphorin receptors: cell signalling for invasive growth," Nature Reviews Cancer, vol. 2, no. 4, pp. 289-300, 2002.

[114] C. P. Webb, C. D. Hose, S. Koochekpour et al., "The geldanamycins are potent inhibitors of the hepatocyte growth factor/scatter factor-met-urokinase plasminogen activatorplasmin proteolytic network," Cancer Research, vol. 60, no. 2, pp. 342-349, 2000.

[115] A. Nusrat, C. A. Parkos, A. E. Bacarra et al., "Hepatocyte growth factor/scatter factor effects on epithelia. Regulation of intercellular junctions in transformed and nontransformed cell lines, basolateral polarization of c-met receptor in transformed and natural intestinal epithelia, and induction of rapid wound repair in a transformed model epithelium," Journal of Clinical Investigation, vol. 93, no. 5, pp. 20562065, 1994.

[116] T. Dschietzig, C. Bartsch, G. Baumann, and K. Stangl, "Relaxin-a pleiotropic hormone and its emerging role for experimental and clinical therapeutics," Pharmacology and Therapeutics, vol. 112, no. 1, pp. 38-56, 2006.

[117] L. Chan, M. Hossain, C. Samuel, F. Separovic, and J. D. Wade, "The relaxin peptide family-structure, function and clinical applications," Protein and Peptide Letters, vol. 18, no. 3, pp. 220-229, 2011.

[118] S. Nistri, M. Bigazzi, and D. Bani, "Relaxin as a cardiovascular hormone: physiology, pathophysiology and therapeutic promises," Cardiovascular and Hematological Agents in Medicinal Chemistry, vol. 5, no. 2, pp. 101-108, 2007.

[119] R. G. Bennett, S. R. Dalton, K. J. Mahan, M. J. GentryNielsen, F. G. Hamel, and D. J. Tuma, "Relaxin receptors in hepatic stellate cells and cirrhotic liver," Biochemical Pharmacology, vol. 73, no. 7, pp. 1033-1040, 2007.

[120] X.-J. Du, R. A. D. Bathgate, C. S. Samuel, A. M. Dart, and R. J. Summers, "Cardiovascular effects of relaxin: from basic science to clinical therapy," Nature Reviews Cardiology, vol. 7, no. 1, pp. 48-58, 2009.

[121] S. Kageyama, K. Nakamura, and J. W. Kupiec-Weglinski, "Relaxin in liver transplantation: a personal perspective," Molecular and Cellular Endocrinology, vol. 487, pp. 75-79, 2019.

[122] M. Malviya, A. Ohisson, and S. Shah, "Surgical versus medical treatment with cyclooxygenase inhibitors for symptomatic patent ductus arteriosus in preterm infants," Cochrane Database of Systematic Reviews, vol. 23, no. 1, Article ID CD003951, 2008.

[123] A. Malinin, A. Pokov, M. Spergling et al., "Monitoring platelet inhibition after clopidogrel with the VerifyNowP2Y12 rapid analyzer: the VERIfy Thrombosis risk ASsessment (VERITAS) study," Thrombosis Research, vol. 119, no. 3, pp. 277-284, 2007.

[124] N. Kawada, H. Klein, and K. Decker, "Eicosanoid-mediated contractility of hepatic stellate cells," Biochemical Journal, vol. 285, no. 2, pp. 367-371, 1992.

[125] K. Decker, "Biologically active products of stimulated liver macrophages (Kupffer cells)," European Journal of Biochemistry, vol. 192, no. 2, pp. 245-261, 1990.

[126] G. He and M. Karin, "NF- $\kappa$ B and STAT3-key players in liver inflammation and cancer," Cell Research, vol. 21, no. 1, pp. 159-168, 2011. 
[127] N. Selzner, H. Rudiger, R. Graf, and P. A. Clavien, "Protective strategies against ischemic injury of the liver," Gastroenterology, vol. 125, no. 3, pp. 917-936, 2003.

[128] M. A. Hossain, I. Hamamoto, H. Wakabayashi et al., "Experimental study of the effect of intraportal prostoglandin E1 on hepatic blood flow during reperfusion after ischaemia and hepatectomy," British Journal of Surgery, vol. 86, no. 6, pp. 776-783, 1999.

[129] K. Skwarło-Sońta and P. Majewski, "Melatonin, multifunctional Signac molecule in mammals: origin, functions, mechanisms of action," Folia Medica Lodziensia, vol. 37, no. 1, pp. 15-55, 2010.

[130] P. Stiegler, A. Bausys, B. Leber et al., "Impact of melatonin in solid organ transplantation-is it time for clinical trials? A comprehensive review," International Journal of Molecular Sciences, vol. 19, no. 11, p. 3509, 2018. 


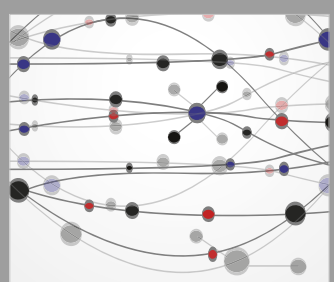

The Scientific World Journal
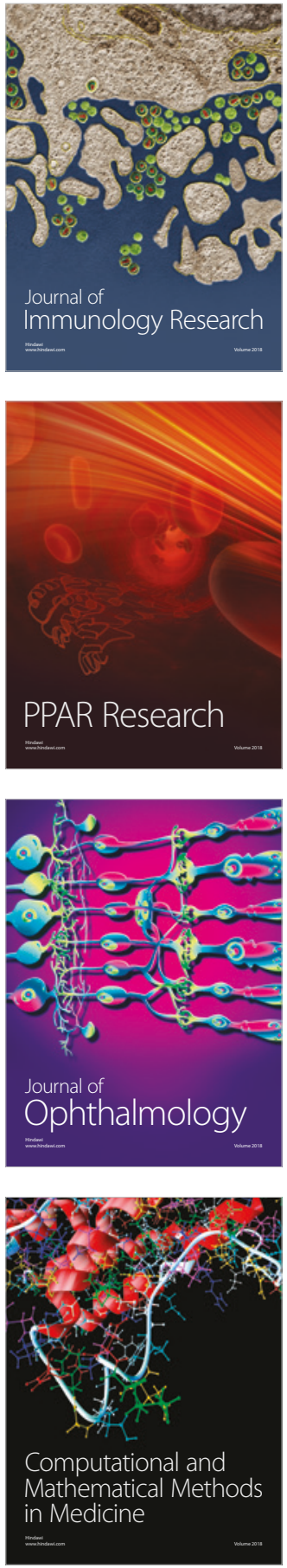

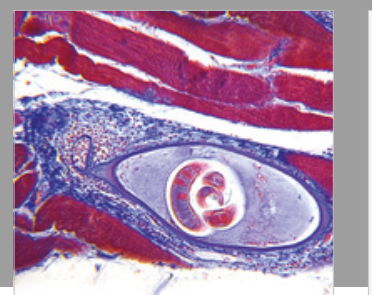

Gastroenterology Research and Practice

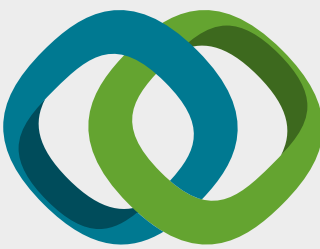

\section{Hindawi}

Submit your manuscripts at

www.hindawi.com
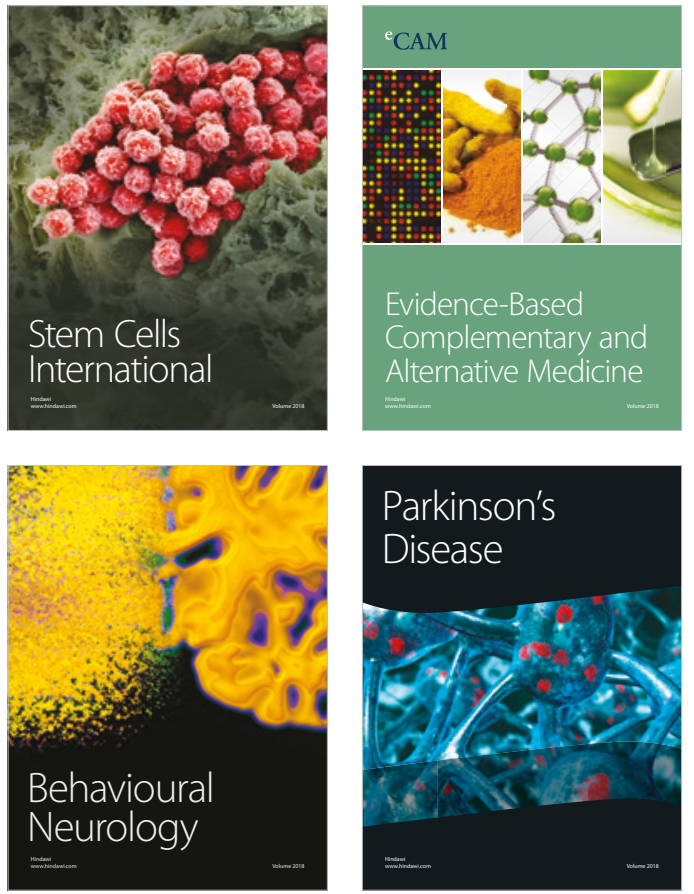

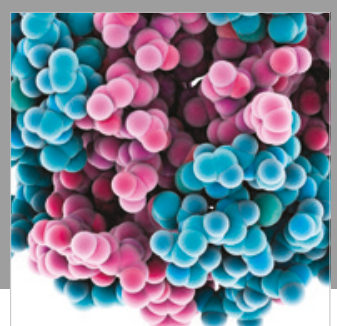

ournal of

Diabetes Research

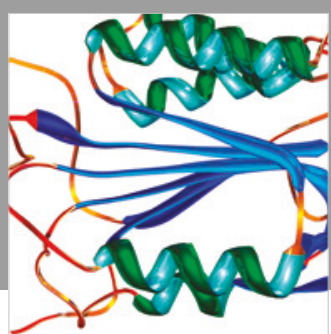

Disease Markers
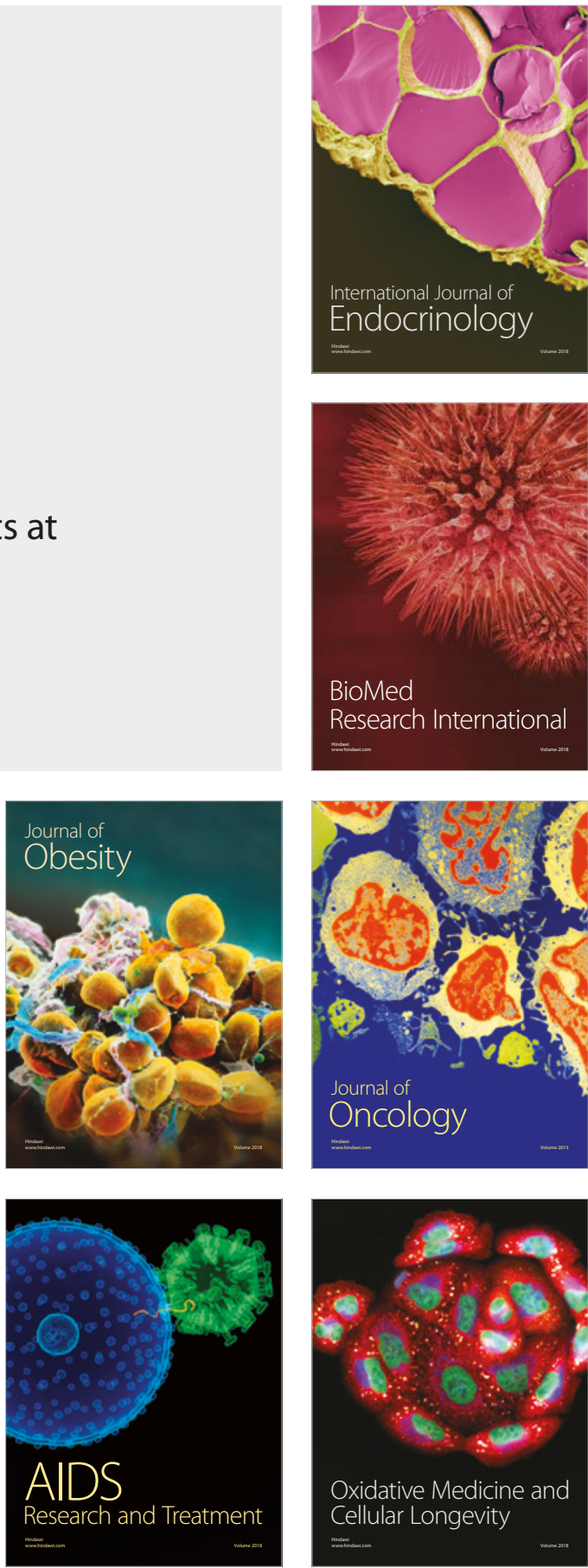